\title{
A Umbanda nos romances espíritas kardecistas
}

\author{
DOI: 10.3395/reciis.v4i3.385pt
}

\section{Maria Helena Villas Boas Concone}

Professora Titular do Departamento de Antropologia da PUC/SP, orientadora nos Programas de Pós Graduação em Ciências Sociais e em Gerontologia da PUC-SP; membro do Centro de Estudos da Religião Douglas Teixeira Monteiro (CER); membro de Comitê de Ética em Pesquisa na Área de Saúde Pesquisadora nas áreas de Antropologia da Religião e da Saúde/Doença com ênfase nos seguintes temas: umbanda, religião, saúde, corpo e envelhecimento. São Paulo, Brasil.

trcconcone@yahoo.com.br

\section{Eliane Garcia Rezende}

MSc em Epidemiologia, Professora na Universidade Federal de Alfenas (UNIFAL-MG), doutoranda na área de Antropologia do Programa de Pós Graduação em Ciências Sociais da PUC/SP, com estudos sobre Instituições, Ideologias e Religiões. Alfenas, Minas Gerais, Brasil. eliane.rezende@unifal-mg.edu.br

\begin{abstract}
Resumo
Para a Antropologia, a religião pode ser vista como um sistema cultural que engloba todo um conjunto de símbolos e significados, onde são contruídas relações de sentido para a vida; como afirma Geertz, a religião produz um ethos e uma visão de mundo. Este estudo teve como objetivo analisar a Umbanda tal como aparece em romances espíritas, buscando os aspectos morais e cognitivos que os informam, neste caso buscando, na visão espírita do umbandismo, a positividade ou a negatividade a ele atribuídas e os argumentos usados para justificar tais avaliações. Os textos escolhidos permitiram o cotejamento entre as descrições e recortes feitos nesses romances e as descrições e recortes da Umbanda apresentados pela literatura acadêmica. Esta estratégia permitiu aprofundar nossa análise e, indo um pouco além dos romances, introduzir uma reflexão mais crítica. Para a leitura e análise dos textos estabelecemos previamente alguns marcadores: nascimento da Umbanda; obsessão ou encosto; sincretismo; processo saúde-doença. A explicabilidade oferecida pelo Espiritismo mostra toda sua força para as pessoas que vivem infortúnios (morte, perdas, doenças,entre outros) e as descrições das atuações da Umbanda e do Espiritismo são vistas nesse contexto como uma soma de ações em benefícios dos indivíduos encarnados e desencarnados.
\end{abstract}

\section{Palavras-chave}

religião; umbanda; espiritismo kardecista; antropologia interpretativa; romances
A Umbanda, que se desenhou no Brasil com esse nome a partir das primeiras décadas do Século $X X$, pode ter representado, segundo alguns estudiosos, um campo de concorrência para o Espiritismo Kardecista (LEWGOY, 2001). De outra perspectiva, contudo, pode-se dizer que estes dois campos religiosos estabeleceram um diálogo, nem sempre de dupla mão, é bem verdade. Já tivemos oportunidade de lembrar que a Umbanda foi se construindo num processo de busca de legitimação social e religiosa, busca essa sujeita a pressões internas e externas. Desde a adoção da denominação atual (que abrange um campo bastante diferenciado internamente) a Umbanda transitou entre pressões socioculturais e políticas. Nesse esforço de legitimação o Espiritismo Kardecista presente no Brasil desde meados do Século XIX, ofereceu um repertório de fácil re- tradução para umbandistas e outros adeptos de cultos afro-brasileiros. Um repertório e um grande guarda chuva defensivo. A Umbanda é uma religião de transe de possessão ou religião mediúnica, como frequentemente seus adeptos preferem falar. Apesar do diálogo - feito de adequações e ressignificações - entre as ideias vindas do Espiritismo e da Umbanda e da importância dada por ambas à mediunidade, pode-se dizer que desde o período de seu "nascimento" no Brasil até entrada dos anos 2000, a Umbanda tem, de modo geral, uma aceitação extremamente tímida entre os kardecistas. Como aponta Lewgoy (2001), o espiritismo no Brasil é religião letrada e racionalista, que "é adotada pelos segmentos de elite do Brasil pré-republicano". A entrada dos cultos de origem africana entre nós, por outro lado, contou uma história exatamente oposta àquela. Mesmo que 
alguns dos pioneiros do Kardecismo tenham participado de causas como o abolicionismo e a república, como bem lembra Lewgoy (2001), o espiritismo se populariza "não pelo heroísmo ou pelo profetismo", mas pela oferta de serviços de cura. Segundo esse mesmo autor, esta popularização irá levar a movimentos de fragmentação interna exercida por concorrência com outras religiões mediúnicas, como aconteceu em sua relação com a Umbanda. Em seu trabalho sobre "Chico Xavier e a cultura brasileira", Lewgoy diz que o "espiritismo exposto na vida e obra de Chico Xavier", resume a relação com a Umbanda e outras questões, em três pontos. Situa em primeiro lugar o sincretismo da Umbanda como primitivo; vê a mistura da religião e política, do positivismo, como promíscua; finalmente, considera a síntese espírita de "religião, filosofia e ciência como desejável, racional e espiritualmente evoluída". Estas considerações mostram alguns aspectos pejorativos da visão Espírita brasileira sobre a Umbanda. Bairrão et al. (2003) lembram que a Umbanda habitualmente é vista como uma espécie de "subproduto ideológico".

Como dissemos acima, esta religião sempre transitou entre pressões socioculturais e políticas como o recorte de classes, o preconceito de marca, a desvalorização das origens africanas, a desvalorização especificamente das origens Banto, a condenação de práticas etc. Sua estrutura, flexível a novas influências, foi se fazendo entre os eixos de possibilidades, de desejos e criatividade de seus praticantes. Na sua prática religiosa observa-se a composição de vasto universo simbólico e de rituais que são síntese de elementos culturais de diferentes proveniências, realizada por seus autores - pais e mães de santo - que retraduzem suas próprias influências religiosas. De nossa perspectiva, mesmo a adoção do nome Umbanda, para batizar uma Macumba (ela mesma matizada de influências diversas) vista com desconfiança e preconceito, fez parte daquele movimento de legitimação. Por outro lado, do ponto de vista da aceitação social, como dissemos, podese apontar que o processo de entrada do Kardecismo no Brasil se fez de modo praticamente oposto à entrada das religiões africanas: estas vieram pelas mãos de escravos e de culturas vistas como "primitivas", provenientes do continente africano; aquele entrou pelas mãos de homens livres, estudiosos e intelectuais e vindo diretamente da França, no continente europeu. Assim, definindo-se como "espiritualista", a Umbanda forçava uma brecha de aceitação social. Por outro lado, partilhando, ou crendo partilhar, com o Kardecismo a mesma crença nos espíritos e na comunicabilidade entre os mundos dos vivos e dos mortos (do visível e do invisível, dos espíritos e dos homens), as traduções e ressignificações se fizeram de modo relativamente fácil para os umbandistas. $\mathrm{O}$ inverso não se fez sentir com a mesma força. A identificação não foi imediata ou tranquila por parte da sociedade e dos próprios kardecistas. Notícias de jornais do início do século passado e final do anterior fazem claramente a distinção entre "baixo espiritismo" (Macumba/Umbanda) e "alto-espiritismo" (Kardecismo). Depoimentos de umbandistas egressos do espiritismo dão conta da necessidade de abandonar os centros espíritas para formar casas de Umbanda onde seus Guias - pretos e caboclos - "pudessem trabalhar". Tudo isto responde pela aceitação acima chamada tímida, da Umbanda pelo Espiritismo Kardecista.

Nas relações entre Umbanda e Espiritismo, não podemos esquecer que nos processos de ressignificação, a cosmologia umbandista incorpora elementos da cosmologia espírita. Não podemos deixar de considerar também que, na formação das religiões de matriz africana no Brasil, o sincretismo religioso interafricano esteve sempre presente; tampouco pode-se deixar de considerar a incorporação e ressignificação de elementos de outras realidades religiosas, especialmente a incorporação primeira de elementos cristãos pela via do catolicismo dominante ao tempo da escravidão. Finalmente, não podemos deixar o Espiritismo fora desse campo de trocas e ressignificações, por isso já se fala num Espiritismo à brasileira (como se fala de um Catolicismo à brasileira).

\section{À guisa de desenvolvimento}

Na perspectiva de realizar uma análise sobre a Umbanda descrita por escritores espíritas, buscamos em Geertz (1989) a estratégia da "descrição densa". Lembrando Geertz, quando diz que cada aproximação é um avanço em relação às que a precederam, realizamos um esforço para descrever a visão da Umbanda em romances psicografados no Espiritismo Kardecista. Estamos, portanto, realizando sucessivas leituras sobre o mesmo evento, produzindo uma espécie de aprofundamento de análise. No caso da análise de romances espíritas, podemos aceitar a indicação de Geertz de que estamos realizando interpretações pelo menos de "terceira mão"; de fato, nos textos que privilegiamos neste artigo - os de Robson Pinheiro -, podemos pensar em interpretações de "quarta mão". A primeira interpretação será de um espírito desencarnado (Sérvulo) que narra os fatos "como eles ocorreram" para um segundo espírito (Angelo Inácio), que fará a segunda interpretação e narrará novos fatos tais como vividos por ele; finalmente, este segundo espírito desencarnado, na qualidade de mentor, passará as informações e reflexões ao médium (Robson Pinheiro), que as psicografa. Os textos que escolhemos se "materializam" 
pela interferência desse terceiro descritor (o médium), o que justifica dizer que nosso trabalho corresponde, portanto, à quarta leitura interpretativa dos eventos. A descrição vai ganhando novas interpretações coerentemente com a tradição da antropologia que nos serviu de baliza, que se coloca como uma ciência interpretativa à procura de significados; no nosso caso, significados não apenas religiosos. Como diria Geertz, esta é uma "interpretação de quarta mão", buscando adensamento graças ao alargamento de repertório, a partir de cada uma das interpretações precedentes.

É nessa perspectiva que procuramos responder: como a Umbanda é descrita em romances Espíritas? Existe diferença entre a descrição feita na literatura espírita "Kardecista" e os relatos de estudos acadêmicos sobre a Umbanda? Esta última questão poderá ser respondida a priori positivamente, pois a nossa leitura final, como de outros tantos estudos antropológicos, não estará comprometida com a visão do crente ou do adepto. Procuramos manter tanto quanto possível o distanciamento balanceado pelo mergulho cúmplice nessa realidade religiosa, social e cultural. O olhar crítico, afinal, é um dever de ofício.

Nesta perspectiva, traçamos o objetivo principal deste estudo como sendo a análise da Umbanda tal como aparece em romances espíritas, destacando especialmente a positividade ou a negatividade atribuídas a essa religião e quais os argumentos usados em cada caso para justificar a avaliação. Os textos escolhidos especificamente para este trabalho permitem o cotejamento entre as descrições e recortes feitos nesses romances e as descrições e recortes da Umbanda apresentados pela literatura acadêmica.

A Antropologia Interpretativa de Geertz (1989) propõe uma conceituação semiótica de cultura que se constituiria das "teias de significados construídos pelos homens envolvendoos". A tarefa do antropólogo, diz ele, será de desvendar e chegar a uma descrição densa dessas teias. Contextos mais ou menos específicos, sistemas que mostram uma certa lógica de amarrações, caracterizam culturas particulares e nichos dentro de culturas particulares. Nossa proposta é a de tomar romances espíritas como uma brecha que permita penetrar num desses nichos, buscando descrever, de forma mais densa possível, as teias de significados que aí envolvem a religião umbandista e o contexto social, remetendo aos princípios religiosos que os autores explicitam.

A literatura espírita é muito vasta e, no que tange a publicações e vendas, são milhões de livros colocados à disposição dos leitores, com uma diversidade de autores representados pelos seus médiuns. A psicografia, carrochefe deste mundo editorial, conta inúmeras obras ditadas por "espíritos desencarnados" e revelam cifras significativas, como: mais de 25 milhões de livros vendidos de Chico Xavier, mais de 7,5 milhões de Divaldo Franco e mais de 5 milhões de Zíbia Gasparetto (STOLL, 2005). Neste universo, os livros que tratam da atuação da Umbanda tomando-a realmente como tema central, não são tão numerosos e o médium Robson Pinheiro é pioneiro nesse trabalho. Esta empreitada, segundo ele, é terreno árido, pois enfrenta o enorme preconceito dos seguidores espíritas que tratam a Umbanda como "baixo espiritismo". Mesmo diante desse estigma, o livro de Pinheiro - "Tambores de Angola", lançado em 1998, atingiu cifras expressivas, com mais de 130 mil exemplares vendidos até abril de 2009. Por ser pioneiro na abordagem da Umbanda em romances espíritas, escolhemos para o presente estudo suas psicografias: Aruanda, Legião e Tambores de Angola.

De fato, esta é a nossa segunda incursão pelo romanceiro espírita, pois anteriormente fizemos a leitura de uma parte da produção de Zíbia Gasparetto. Em Gasparetto vasculhamos a questão da saúde e da doença e este tema permite verificar as reiterações de fundo, comuns aos livros espíritas. Na abordagem da doença, do sofrimento e da morte, há sempre um esforço em todos eles de encontrar explicações para tais eventos ou, pelo menos, como diria Geertz, de não perder a sua explicabilidade; o sofrimento e a doença são atribuídos à responsabilidade do sofredor e reintegrados na sua biografia que, como já dissemos em outro artigo, não se esgota no prazo de uma vida. No que concerne à visão da Umbanda, contudo, pudemos verificar as diferenças entre as abordagens especificamente de Zíbia e as de Robson Pinheiro. No romance "Ninguém é de ninguém", Zíbia abordou atividades de terreiro que surgem sempre como negativas (com pequenas nuances), quando pais-de-santo ignorantes ou mal intencionados colocam os personagens em caminhos equivocados, elaborando trabalhos que visam o mal de alguém. Inveja, ciúme, vingança, desconfiança, possessividade, entre outros, traduzidos ou não em "coisa feita", são caminhos certos para o sofrimento e para o não aprimoramento do espírito. Robson não nega a lei da "ação e reação", nem o efeito maléfico para encarnados e desencarnados do mau uso das necessidades e desejos; entretanto, como veremos adiante, sua visão da Umbanda não é negativa. Ele empresta um lugar importante a esta religião no processo de burilamento do espírito. Para tanto ele deve definir a "verdadeira Umbanda", reconstruir a sua história e mostrar os espíritos de luz que nela atuam.

A partir de uma revisão de alguns trabalhos acadêmicos importantes na área foi possível aprofundar nossa análise da 
complexa interrelação entre as características descritas para a atuação da Umbanda em nossa sociedade, contrapondoas com as descritas em romances espíritas. Para o intento, estabelecemos previamente alguns marcadores, quais sejam: o nascimento da Umbanda; a obsessão ou encosto; o sincretismo; o processo saúde-doença.

\section{Aspectos da literatura Espírita}

No Espiritismo, a comunicação com os espíritos é muito presente e as narrativas vão desde simples episódios e mensagens de parentes mortos, até as mais complexas histórias. Os autores (espíritos) relatam, com naturalidade, a vida no mundo dos desencarnados (mundo do Além) e toda a dinâmica da vida dos espíritos interferindo no mundo material ou corpóreo. É por este tipo de narrativa que os conteúdos assumem a aura de "fatualidade" (GEERTZ, 1989), uma "fatualidade religiosa" que narra os fenômenos espíritas. Poucas narrativas espíritas, neste contexto da psicografia tratam da história e atuação da Umbanda. Os romances psicografados por Robson Pinheiro são colocados como proposta para que a Umbanda e o trabalho de pretosvelhos, exus e caboclos sejam vistos, nas palavras do autor, de uma maneira menos preconceituosa pelos adeptos do Espiritismo Kardecista. O editor se propõe como contribuinte, inclusive no meio espírita, para quebrar tabus referentes aos papéis que aqueles agentes da Umbanda desempenham na estrutura da sociedade, seja no plano dos encarnados ou no dos desencarnados.

Inspiradas em Godoy (2009), observamos a 'Geografia da Religião' estabelecida no fenômeno espírita e tentamos entender, nos romances analisados, a "espacialidade através de suas narrativas". Para Godoy (2009) a espacialidade narrativa compreende as relações entre plano espiritual e terreno do mundo religioso. Neste contexto, os romancistas Zíbia Gasparetto e Robson Pinheiro psicografam os dramas da vida, descritos em palcos diferentes. Nos romances de Robson Pinheiro os fatos se passam no ambiente dos desencarnados (espaço do Além - espiritual; sendo os narradores espíritos desencarnados, eles dizem "o mundo do lado de cá"), enquanto que em Zíbia as histórias - dramas se passam no plano dos encarnados (espacialidade do aqui, material). Tratar cada um dos espaços como "aqui" e "lá" ou "além" (Zíbia) e "mundo de cá" e o "mundo de lá", fazendo o contraponto entre o mais próximo e o mais remoto, sinalizam o lugar de onde os autores falam. Em resumo, as sinalizações são relativas, dependendo do lugar do narrador e dos eventos narrados. Nessa perspectiva da "geografia da religião", pode-se desde já ressaltar que os espaços dos espíritos, ou desencarnados, em Robson são bastante numerosos e diferenciados: há vários espaços habitados por diferentes grupos de espíritos e os mais evoluídos podem transitar entre eles. Nesses espaços astrais há pontos de recepção de espíritos recém-desencarnados, necessitados de ajuda e que a recebem em "hospitais" (ou "câmaras de socorro"), por meio de espíritos evoluídos que se propuseram a missão de ajudá-los. Pinheiro fala ainda de uma espécie de limbo (expressão nossa) feito de energias densas, situado entre as esferas mais elevadas e de energias mais sutis e o mundo dos encarnados. Este lugar desolado, mostrado em cores escuras, feito de uma espécie de "lama astral" na qual estão mergulhados espíritos sofredores, conta também com "Oásis" de ajuda, onde atuam espíritos elevados e abnegados (PINHEIRO, 2004).

Quanto ao modo de ver a Umbanda, em Zíbia temos a descrição de um terreiro onde são desenvolvidas atividades como despachos e trabalhos executados pelo indivíduo que foi chamado a ser o executor das vontades de um espírito (mentor). Um mentor que orienta tarefas para atender aos desejos imediatos dos homens e que não se preocupa com as consequências, a longo prazo, das suas atitudes. Utiliza-se de entidades desencarnadas para provocar nos encarnados sentimentos ruins e estimular atitudes que irão corresponder a tais desejos imediatos do solicitante do despacho. A descrição do terreiro é simples, mas remete à percepção de atividades que geralmente são condenadas pela doutrina Espírita Kardecista, corroborando a visão de que a Umbanda seria um movimento de 'baixo espiritismo', algo que não representa, ou não permite, uma "evolução" moral, levando a tomar atitudes comprometedoras da saúde dos indivíduos, seja no plano dos encarnados ou no dos desencarnados.

Nos romances de Robson Pinheiro, pelo contrário, as descrições dos terreiros de Umbanda são detalhadas e há distinção entre os templos de Umbanda e outros barracões ou terreiros que remetem a atividades de Quimbanda ou Candomblé. No romance "Aruanda", encontraremos uma abordagem conceitual e as características do que seria "um umbandista verdadeiro": "médiuns umbandistas usam a roupa branca, como característica de simplicidade, e não entoam cantos rituais em idiomas que não o português, abolindo inclusive o uso de atabaques" (PINHEIRO, 2004). Nos três romances analisados a abordagem tende a estabelecer que as atividades da Umbanda e o papel dos pais e mães de santo são valiosos, mas são diferentes das atividades espíritas kardecistas. Estas diferenças remetem à atuação em planos 
energéticos distintos, sendo "os mais densos" destinados aos umbandistas e os mais "sutis" destinados à atuação dos espíritas kardecistas.

Ao enfrentar o que considera o desafio de levar aos espíritas kardecistas, entre os quais se inclui Robson Pinheiro, uma visão da Umbanda livre de preconceitos, o próprio espírito Angelo Inácio justifica a empreitada e defende o médium. Ângelo Inácio assina o prefácio de Aruanda e se apresenta como um jornalista e um escritor, nas suas palavras:

Este não é um livro que pretende falar da doutrina da umbanda. É mais uma obra que valoriza o trabalho dos espiritos que se utilizam da roupagem fluídica de paisvelhos e caboclos, auxiliando a humanidade encarnada e desencarnada. Talvez seja mesmo um grito contra o preconceito religioso, racial e espiritual, mostrando quanto os espíritos superiores trabalham muito além das aparências. (PINHEIRO, 2004, Prefácio).

Mais adiante, no corpo do livro o espírito autor registra:

Uma das coisas que mais nos divertiu aqui na nossa comunidade, foi observar a "lógica" de muitos companheiros espíritas diante das nossas observações registradas no livro Tambores de Angola. Para eles se o médium escreveu algo a respeito da umbanda, é porque se tornou umbandista. (...) Se o pobre rapaz psicografou um livro de determinado autor desencarnado, diz a lógica de nossos irmãos que foi filho desse espírito em outra encarnação. (PINHEIRO, 2004).

Finalmente, escreve ainda:

Uma vez mais, venho escrever sobre o povo de Aruanda, mostrar sua cor, seu jeito, seu sabor ao desempenhar o trabalho do bem. (PINHEIRO, 2004).

Vê-se que a tarefa do autor não é fácil e exige coragem. Não queremos nos estender nestes pontos, mas pode-se notar, salvo melhor juízo, que apesar do esforço de resgatar a Umbanda do preconceito, em muitos momentos o modo de se referir aos espíritos encarnados ou desencarnados atendidos por ela, reproduz, em larga medida, sob outra luz, muitos dos preconceitos que quer combater. O capítulo de Aruanda chamado Região de Transição traz passagens que justificam esta interpretação. É o caso da mudança de aparência dos espíritos quando se aproximam da referida região: "Paulatinamente as feições de Euzália transfiguraramse [...] A aparência clara de tipo europeu, tomou as características de uma negra, sem perder porém a delicadeza no olhar e a simplicidade do espírito nobre". Adiante no mesmo capítulo, o autor fala do apelo ouvido de "alguém em intenso sofrimento: Socorram-me, socorram-me! Porque nóis? Me ajudem, eu preciso sair deste inferno".

Como podemos ver, a dupla de escritores se antecipa à nossa interpretação de que há nos seus textos um reforço disfarçado do preconceito, justificando que a Umbanda - e seus pretos-velhos e caboclos - seria necessária para que o ideário espírita, vazado numa linguagem erudita, pudesse atingir a população menos culta. Este caminho leva necessariamente ao estabelecimento de uma linha divisória entre a "verdadeira" e a "falsa" Umbanda.

Contudo, o espiritismo de Allan Kardec, recém-chegado da França na segunda metade do séc. XIX era muito intelectualizado para falar aos barracões do candomblé. Atendia, à época, apenas aos anseios da camada mais culta da população brasileira, acostumada com a linguagem europeia e os diálogos da filosofia clássica. Então, alguém propõe, na assembleia de espíritos elevados: "Que tal uma religião nova, que reúna ambos os conhecimentos, levando espiritualidade ao culto popular?". Nasce então a aumbandhã, ou umbanda - a união das duas bandas. (PINHEIRO, 2004)

\section{Dos marcadores}

\section{O nascimento da Umbanda}

O surgimento da Umbanda ainda mobiliza diversas discussões que envolvem a questão das origens, um campo muito fértil para reflexões sobre um fenômeno que representa a legitimação de movimento religioso. É a busca de um início para compor a história de um movimento que tenta estabelecer um espaço na sociedade, e necessita de uma espécie de "memória" para se materializar - um "movimento histórico fundador" segundo Rohde (2009). Este movimento fundador precisa representar, perante a sociedade, uma relevância funcional, constituir-se em um bem social de mérito como produto de transformações ocorridas no contexto social e cultural. Falar de nascimento remete à abordagem de um evento que necessita de um tempo e espaço bem delimitados; precisa-se mostrar o espaço físico, o espaço geográfico, o espaço identitário, o tempo cronológico e o tempo mítico para o movimento religioso. Para a Umbanda, tanto estudiosos quanto adeptos sempre procuraram descrever estas variáveis. Pudemos observar que a história das origens, psicografada por Robson Pinheiro em seus romances, adere a uma das linhas de interpretação acadêmica. Precisamente, adere a uma linha que preenche os requisitos acima referidos pois, para dar concretude a uma 
memória, deve-se encontrar o movimento histórico fundador. A visão processual que evita apontar origem precisa e datada não preencheria as necessidades da construção da marca identitária.

Como podemos perceber nas colocações abaixo citadas, os romances espíritas analisados trazem várias afirmações sobre o processo histórico de fundação da Umbanda, corroborando o chamado "mito de origem" (ROHDE, 2009) relatado em estudos de pesquisadores dessa religião afrobrasileira. O autor acolhe e celebra Zélio de Morais como "pai fundador", Niterói como o lugar de nascimento e 1908 como a fase da "pré-história" da verdadeira Umbanda, na qual o mentor por excelência é o Caboclo das Sete Encruzilhadas.

Um dia, quando Zélio estava no meio de um de seus "ataques", a família já completamente apavorada resolve procurar o centro espírita, como último recurso. Era a Federação Kardecista de Niterói. Ali chegaram com o rapaz no dia 15 de novembro de 1908, e quem os recebeu foi exatamente o presidente, o Sr. José de Souza. (PINHEIRO, 2004)

- [...] sou o Caboclo das Sete Encruzilhadas, pois para mim não existem caminhos fechados. Venho trazer a umbanda, uma religião que harmonizará as famílias, unirá os corações, falará aos simples e que há de perdurar até o final dos séculos. [...] A nova religião virá, e não tardará o tempo em que ela falará aos corações mais simples e numa linguagem despida de preconceito. Entre o povo do morro, das favelas, das ruas e dos guetos, será entoada uma cantiga nova. O povo receberá de seus ancestrais o ensinamento espiritual em forma de parábolas simples, diretamente da boca de pais-velhos e caboclos. (PINHEIRO, 2004)

E nascia assim o comprometimento de Zélio de Moraes com a aumbandhã ou, simplesmente umbanda. Uma religião tipicamente brasileira, considerando-se o tipo psicológico com o qual se apresentam as entidades veneráveis que fizeram da umbanda uma fonte de luz e sabedoria para as pessoas que se sintonizam com suas verdades. (PINHEIRO, 2004)

A necessidade de uma demarcação histórica do nascimento de uma nova religião vem acompanhada da reposição de explicabilidade do Espiritismo Kardecista. A relevância da nova religião acompanha os ensinamentos do processo de ação e reação, e se constitui como uma maneira para resgatar ou regenerar pessoas que, durante os processos reencarnatórios anteriores, se deixaram levar pelos excessos no campo do materialismo e dos comportamentos pouco apreciados pela moralidade, especialmente no que se refere à produção da chamada "magia negra".

A magia negra deveria ser combatida e seus efeitos destrutivos haveriam de ser desmanchados de maneira a transformar os próprios centros de atividades dos cultos degradantes em lugares que irradiassem o amor e a caridade, única forma de se modificar o panorama sombrio. Havia necessidade de que espíritos esclarecidos se manifestassem para realizar tal cometimento. E assim, foram se apresentando uma a uma, aquelas entidades iluminadas que haveriam de modificar suas formas perispirituais, assumindo a conformação de pretos velhos e caboclos e levariam a mensagem de caridade através da Umbanda cujo objetivo inicial seria o de desfazer a carga negativa que se abatia sobre os corações dos homens no Brasil. A Umbanda seria o elo de ligação com o Alto; penetraria aos poucos nos redutos de magia negra ou nos terreiros de Candomblé, os quais ainda se mantinham enganados quanto às leis de amor e caridade e iria transformando com as palavras de um preto velho ou as advertências do caboclo, os sentimentos das pessoas. (PINHEIRO, 1998)

Segundo esses textos, no esforço para se criar a nova religião, estabeleceram-se rituais que lhe permitiriam inserirse entre os segmentos sociais menos abastados e menos escolarizados, exatamente aqueles que já aderiam a rituais e crenças em Orixás e em outras energias da natureza; a nova religião procuraria assim obter respaldo e aceitabilidade nestes grupos, adotando os mesmos elementos de culto. A explicação parece cristalina dentro da lógica expressa: o objetivo da formação da Umbanda explicado nestes romances espíritas seria, então, o de combater os desequilíbrios de alguns terreiros de Candomblé; foi visando esta meta que a Umbanda montou sua estrutura com rituais e mitos nos quais se observa também a crença nos Orixás. Ficam no ar algumas perguntas: a Umbanda adota os rituais e existência dos Orixás como forma de se aproximar dos adeptos das atividades de magia negra? Porque a Umbanda teria adotado os rituais de Orixás e não outras formas cristãs de manifestação de crença, já que assume um extenso sincretismo religioso? Será que esta explicação do objetivo de fundação, expressa nos romances espíritas, pode auxiliar também na interpretação do complexo sistema de elementos rituais de seus cultos, reunindo sincreticamente elementos cristãos, da macumba, do kardecismo e outros rituais? 
Claro está que as respostas não podem ser buscadas apenas no conjunto de textos escritos por adeptos, sejam eles romances ou não. É inegável, porém, que a lógica do Espiritismo Kardecista, tal como entendida pelos autores, será sempre um poderoso mecanismo de explicação da realidade religiosa e social e, pelo menos até agora, não parece ter esgotado sua capacidade de dar respostas. Realmente poderíamos lembrar que o panteão umbandista organizado em linhas e falanges, nelas reserva um lugar de chefia a Almas, Santos e Orixás. Poderíamos acrescentar aqui uma outra questão de caráter socioantropológico: não seriam os espíritas, que crêem nos seus Guias ou Mentores e também nos Orixás, de fato crentes entre os quais alguns se colocaram a difícil tarefa da "codificação da Umbanda", sem perder de vista o desejo de conciliação? Os processos de sincretismos ou de sínteses, como alguns preferem chamar, criam tantos problemas quanto resolvem. A figura dos exus é um exemplo bastante claro da dificuldade de conciliar imagens contraditórias colhidas em diferentes repertórios. Vamos nos ater à nossa proposta de leitura e análise de textos espíritas sobre a Umbanda: veremos que estes textos reservam também um espaço para discussão de sincretismo

Nas análises que fizemos identificamos que a concepção de Umbanda nos romances se refere à chamada "Umbanda branca". Várias das colocações dos textos confirmam esta identificação e mostram também que esta é a "Umbanda Verdadeira". Nestes romances outras práticas ritualísticas que envolvem os Orixás, tais como as atividades do Candomblé ou as da Quimbanda, são conceituadas como desvios da Umbanda e tratadas como atividades de menor cunho evolutivo. Tanto no romance "Tambores de Angola" como em "Aruanda", percebe-se a distinção dos diferentes umbandistas.

[...] que a Umbanda é uma religião que guarda muitos elementos ritualísticos, próprios do seu culto, utilizando-se os seus médiuns de roupas brancas como uniformes, de colares, em alguns casos, banhos de ervas, defumadores e todo um instrumental para canalizar as energias psíquicas no trabalho que realizam. (PINHEIRO, 1998)

Muitos pais-de-santo, médiuns e dirigentes de terreiro têm intentado manter o povo na ignorância, utilizando mal certos conhecimentos iniciáticos e alimentando histórias mentirosas sobre guias e orixás. (PINHEIRO, 2004)

O uso de muitas formas de trabalhos nos terreiros e barracões, que diferem inclusive no número de Orixás e tipos de Orixás chamados para atuar em cada caso, é abordado nos romances mediúnicos como desvios dos ensinamentos sagrados da Umbanda. Para fazer frente aos desvios, os romances incluem numerosas recomendações de retomada dos princípios estabelecidos na história da fundação - "mito de origem" - ou a o afastamento de tipos de atividades desenvolvidas em certos terreiros.

Os problemas que às vezes encontramos não se referem a Umbanda propriamente como religião, mas à desinformação das pessoas, ao misticismo e à falta de preparo de muitos dirigentes, o que aliás, encontramos igualmente nas casas que seguem a orientação Kardecista. (PINHEIRO, 1998)

- Este não é um templo umbandista. Os dirigentes desta tenda, não possuindo maiores esclarecimentos sobre as leis da umbanda, adotaram o nome sagrado e se autodenominam umbandistas. [...] Também se pode notar que neste terreiro os médiuns cultuam os orixás à semelhança do candomblé. Na umbanda, é diferente. Reconhecem-se apenas sete orixás, e os respeitamos como vibrações das forças da natureza. (PINHEIRO, 2004)

Urge resgatar nas tendas umbandistas os ensinamentos sagrados do Caboclo das Sete Encruzilhadas, dados no início do movimento, restaurando assim o sentido verdadeiro da caridade despretensiosa, que não compactua com a cobrança nos trabalhos umbandistas. Também é preciso estimular o conhecimento, através do estudo de livros dos mestres da umbanda, sérios e de elevado padrão, como aqueles que contêm os ensinamentos trazidos pelo venerável Matta e Silva e seus iniciados. (PINHEIRO, 2004)

Nessa perspectiva, a Umbanda vem cumprir um papel. $\mathrm{O}$ papel de resgate daqueles que devem ser ajudados e, por assim dizer, depurados para garantir a sua evolução espiritual - "A única maneira de transformar as atividades dos cultos degradantes, de modificar o panorama sombrio" seria, então, por intermédio de espíritos esclarecidos, entidades iluminadas, que graças ao seu desprendimento caridoso e seu amor ilimitado, embora racional e realista, se dispõe a modificar suas formas perispirituais assumindo as de pretos velhos e caboclos. É exatamente nesse sentido que dissemos acima que o surgimento da Umbanda é explicado dentro da lógica do Espiritismo.

\section{Sobre o Sincretismo}

Rohde (2009) em suas reflexões sobre a "Umbanda, uma religião que não nasceu:[...]" chega a mencionar a Umbanda como resultado de uma reordenação entre a 
macumba, elementos de prática indígena, valores católicos com acréscimos do kardecismo. Esta religião se organiza, portanto, da união de vários elementos de várias crenças, apresentando sempre acréscimos e transformações que perpassam pelos valores culturais de seus pais e mães de santo (VILLAS BOAS CONCONE, 2003). É dessa capacidade de síntese dos vários elementos religiosos que se realiza a prática altamente sincrética da Umbanda. É Giglio-Jacquemot (2006) que talvez melhor expresse este comportamento sincrético, quando afirmou que desde sua origem a Umbanda mostra sua "capacidade prodigiosa em ingerir e digerir materiais culturais de todo tipo e de toda proveniência".

Os romances espíritas psicografados por Robson Pinheiro irão abordar a prática do sincretismo da Umbanda de uma forma bem clara, principalmente com relação aos santos católicos. Mas estas referências, como podemos visualizar nas expressões abaixo, trazem uma explicação do fenômeno como forma de estabelecer comunicação com seus adeptos que migraram de outras práticas religiosas, ou como forma para aceitação social e das autoridades, buscando sobreviver a possíveis pressões políticas. O sincretismo é expresso como uma estratégia de se legitimar para atingir seus objetivos de criação. Sendo assim, poderá somar práticas e rituais de outras crenças, fundindo ou reelaborando uma nova concepção de religiosidade.

[...] Como vibração e energia primordial, os orixás tal e qual guardam determinadas características que se assemelham muito às de certos santos do culto católico. Daí faz todo sentido o chamado sincretismo, aspecto muito marcante e interessante da cultura brasileira. Mas não significa que os orixás sejam tais santos, absolutamente. São princípios ativos, não encarnantes, e se porventura a umbanda utiliza imagens de santos católicos para simbolizar os orixás, é apenas a fim de estabelecer uma conexão mental entre o povo e as verdades da umbanda, através da crença popular. (PINHEIRO, 2004)

Existe outro orixá cultuado no candomblé que também é muito conhecido. Falo de Omulu, que, no sincretismo, corresponde a São Lázaro. (PINHEIRO, 2004)

[... "É assim que, na atualidade, sobrevive nos terreiros essa fusão, que era objetivo do Alto. Adotando o sincretismo entre os orixás e os santos católicos, que há muito se desenvolvia, e o transe mediúnico assumido, que não existia nos barracões de candomblé, a umbanda foi penetrando lentamente nos redutos de magia negra. [...] Se, de todo, a pressão política ou religiosa fosse muito forte, também havia um santo qualquer no nome da casa. E que, em um país católico, com setores conservadores na sociedade, Tenda Espirita de Umbanda Nossa Senhora do Rosário soaria melhor que se o nome fosse apenas Pai Oxalá ou Caboclo Rompe-Mato. (PINHEIRO, 2004)

- A umbanda respeita a riqueza do culto afro, representado no candomblé, mas o referencial para os trabalhos umbandistas são apenas os sete principais orixás-vibração originais, que representam também os sete planos vibratórios do universo, os sete chacras e os sete corpos espirituais. (PINHEIRO, 2004)

Na perspectiva desses romances espíritas, a Umbanda traz a riqueza dos cultos afro-descendentes, acrescida de muitos outros elementos e práticas religiosas, para poder "falar a linguagem do povo". Neste sentido assume uma abrangente compreensão do homem em seu meio, admitindo a explicabilidade do Espiritismo Kardecista e somando-a outros conceitos, inclusive de culturas orientais, como os sistemas energéticos dos chamados "chacras".

Queremos levantar um contraponto de interesse nestas explicações: os textos acadêmicos e o discurso religioso falam com extrema frequência que a identificação, no tempo da escravidão, entre santos e deuses africanos, corresponderia ao mascaramento como uma estratégia de defesa contra os poderosos; no caso da Umbanda, tal como foi aqui apresentada, teríamos uma situação quase inversa, pois esta seria uma estratégia de conquista dos menos afortunados (espiritualmente e culturalmente falando).

\section{Obsessão ou Encosto}

Nos romances mediúnicos encontramos referência à obsessão vista de duas maneiras: iremos observar o conceito dos processos de obsessão ditos simples e os complexos (PINHEIRO, 2006). Os processos simples de obsessão foram entendidos como semelhantes à classificação de encosto para os terreiros de Umbanda e outros cultos de matriz africana. Os processos complexos de obsessão são aqueles que envolvem "o uso de tecnologias desenvolvidas no plano espiritual", usadas para mudar o comportamento do indivíduo através da inserção de "aparelhos parasitas", do uso de "energia magnética e ectoplásmica". Estas inserções são sempre atribuídas ao desejo de fazer malefícios, para que "de diversas maneiras, prejudiquem os filhos encarnados".

No que tange à constituição fisio-astral do ser humano, muitas dificuldades estão além dos processos de obsessão simples, fascinação e subjugação, apontados 
por Kardec e conhecidos no movimento espírita em geral. (PINHEIRO, 2004)

- Portanto, o que vemos aqui também pode ser classificado como magia, se considerarmos que, no processo de obsessão complexa, isto é, com o emprego de aparelhos parasitas, também ocorre a manipulação magnética e ectoplásmica que caracteriza a magia negra. Desse modo, pode-se afirmar que a diferença está na forma exterior, no método, pois os objetivos e princípios aqui aplicados são os mesmos. (PINHEIRO, 2004)

Em Zíbia Gasparetto os processos obsessivos são descritos sem discriminação na ordem da complexidade. Ela atribui a interferência sobre o encarnado como forma de gerar algum prejuízo ao indivíduo, até mesmo no campo de sua saúde física.

Gabriela estava pálida, sem forças, parecia um robô deixando-se conduzir sem nenhuma reação. [...] É um caso de obsessão. Vejo um casal sendo vampirizado. Ela, hipnotizada, está fora da realidade. Ele fez pacto com uma entidade perigosa para conseguir seus fins. (GASPARETTO, 2008).

Roque estava penalizado. Vislumbrara os vultos escuros de espíritos perturbadores ligados ao inesperado visitante, colados como reflexos dos seus próprios movimentos, demonstrando simbiose significativa. [...] O que acontece tem acontecido a muita gente. Espiritos, seus inimigos de encarnações passadas, que não perdoaram, hoje desejam fazer justiça com as próprias mãos, esquecidos de que a justiça pertence a Deus, que para isso estabeleceu Leis que funcionam dando a cada um segundo suas obras. (GASPARETTO, 2003).

Na proposta de cura do processo obsessivo descrito por Zíbia, as atividades de centros espiritas, estabelecendo orientação aos encarnados e desencarnados, serão efetivas para conseguir a cura. Os obsessores são vistos como espíritos de pessoas ignorantes que assumem a posição de algozes, por apresentarem desarmonias com o outro nas relações construídas em vidas passadas. Já em Robson Pinheiro, as descrições das obsessões e seus processos de cura vão além da doutrinação dos algozes e suas vítimas, pois propõe uma união das atividades de desobsessão das diversas frentes religiosas, principalmente da Umbanda e do Espiritismo Kardecista.
[...] É claro que a metodologia utilizada no movimento espírita funciona para diversos tipos de obsessão. Também não menosprezamos os procedimentos umbandistas ou esotéricos, com seus rituais sagrados, símbolos e axés. No entanto, para solucionar a problemática das pessoas afetadas pelas síndromes oriundas de obsessões complexas, como a dos aparelhos parasitas ou da repercussão vibratória de encantamentos e enfeitiçamentos realizados no passado remoto, assim como para enfrentar a ação destruidora das energias elementais, utilizadas pelos magos das trevas, a metodologia consagrada é ineficaz. (PINHEIRO, 2004)

Sobre o processo saúde-doença

A totalidade cultural engloba todo um conjunto de códigos, simbolos e práticas e, nesse terreno fértil, as representações sociais são construídas, fundamentando as relações de sentidos e permitindo a atualização dos significados a cada situação. Nossa busca de interpretação dos sistemas simbólicos espíritas deve ser orientada pelos atos (GEERTZ, 1989), ora, o terreno de atuação nos casos de saúde e doença se presta bastante bem a essa busca.

Este universo simbólico que constitui a cultura, seja de uma sociedade, seja de uma comunidade qualquer, pode trazer em seu bojo, e geralmente traz, a religiosidade como um importante instrumento capaz de dar conta da dinâmica de reorganização de si mesmo e do seu cotidiano, frente a uma condição que torna os indivíduos vítimas da desordem do mundo. Berger (1985) e Luckman, além do próprio Geertz, apontam a capacidade das religiões de resgatar o mundo dos homens do cáos pela atribuição do nomos. Buscar o ambiente religioso representa recriar significações frente aos problemas que a vida cotidiana coloca e permitir motivações para melhoria da situação rumo à explicabilidade. Uma das motivações para procura das religiões é a busca da cura de enfermidades. Muitas vezes aqueles que procuram são pessoas que passaram pelo atendimento médico clássico e não encontraram solução, mas, mais importante, não encontraram aí explicação para o sofrimento. Essa dupla entrada de busca de cura e de busca de sentido permite que haja convivência (especialmente por parte da clientela) entre medicina científica e medicina religiosa. Do ponto de vista daquele que busca alivio para si ou para outros, essas formas são complementares. De fato, as respostas da ciência não esgotam a necessidade de atribuição de sentido. No universo das religiões mediúnicas, os dois processos de cura, o 
profano e o sagrado, frequentemente convivem nos mesmos espaços. Nos romances trabalhados, cura do corpo e cura do espírito, debilitação do espírito e doença física são, no fundo, a mesma realidade e, dessa forma, o concurso de médicos do corpo e médicos do espírito é fundamental.

A religião, portanto, representa um despertar do indivíduo para o sagrado e pode ser produtora de significados, buscando explicações em seus fundamentos filosóficos para as desarmonias que a vida the impõe, sejam de ordem moral, espiritual ou material (GEERTZ, 1989). Frente a uma patologia para a qual nossa medicina tradicional não apresenta perspectivas de cura, na nossa sociedade a busca de lenitivo frequentemente se refugia no campo religioso.

Nos romances analisados, os aspectos das desordens apresentados nas vidas dos personagens são explicados pelo paradigma da reencarnação como princípio básico, seguida da vida dos espíritos em um espaço geográfico do "Além". Mostra-se a morte como uma passagem para a vida espiritual, que é eterna, sendo a vida na terra somente um momento extremamente finito de resgates das atitudes errôneas de vidas anteriores. Nessa perspectiva, as reencarnações são oportunidades de aprendizagem, de fazer evoluir o espírito ou, dito de outro modo, as muitas vidas se apresentam como possibilidades para o processo evolutivo do ser. A doença nada mais é do que situações criadas pela relação do mundo dos espíritos no plano "Além" com os indivíduos encarnados, que se desarmonizam pela consciência dos erros cometidos ou por ação de espíritos vingativos. Nos romances analisados, psicografados por Robson Pinheiro, a perspectiva é sempre a da ação dos espíritos sobre os encarnados ou, sobre as maneiras como o orgulho, a vaidade e o egoísmo debilitam a saúde emocional e física dos homens.

- Nosso irmão é alguém que se comprometeu imensamente com as leis da vida. Abriu campo mental e entrou em sintonia com as forças destrutivas dos magos negros. Tais espíritos diabólicos provocaram o colapso do sistema nervoso de nosso irmão, que, sem conseguir opor resistência à irradiação mental dos magos das trevas, entrou em coma após apresentar quadro clínico de difícil solução para a medicina dos homens. Hoje ele está desprendido do corpo, que repousa no leito do hospital, onde se encontra internado há muitos dias. (PINHEIRO, 2004)

As atividades executadas para resgate da saúde e o processo de cura são descritos como soma das forças dos trabalhos realizados por espíritos no plano astral - espaço do Além - com as atividades desenvolvidas pela nossa medicina no espaço terreno.
Saímos do hospital, confiando o rapaz, já melhor, à equipe espiritual responsável pelo ambiente. Havia muitos casos que mereciam um atendimento especial, mas isso deixaríamos a cargo das demais equipes espirituais que ali prestavam auxílio. (PINHEIRO, 2004)

Por ora - falou Vovó Catarina - nosso protegido ficará repousando aqui, enquanto seu corpo físico permanece em coma no hospital. Amanhã, durante os trabalhos mediúnicos, veremos o que pode ser feito pelo nosso irmão. (PINHEIRO, 2004)

[...] eles conseguem sintonia com a mente invigilante de Erasmino, com seu passado e com sua insistência em manter-se nos mesmos padrões mentais de seus perseguidores. É necessário que ele desperte para a urgência da mudança íntima, elevando seu padrão vibratório, a fim de se desligar dessa influenciação daninha. E, para, isso, a Umbanda, com seus rituais e métodos próprios, será excelente instrumento de despertamento do nosso irmão. Ele encontra-se com o pensamento muito solidificado em suas próprias concepções de vida e, como você vê, não se encontra sensivel aos apelos mais sutis do Espiritismo, que, no momento propício, deverá falar-lhe à razão. Ademais, a família guarda certos pendores para as manifestações de mediunidade tal como se dão na Umbanda, e convém não violentarmos os nossos irmãos." (PINHEIRO, 1998)

O processo de cura das enfermidades pode ocorrer quando a intervenção das equipes de Umbanda se soma com as atividades dos Espíritas kardecistas e outros seres que agem no mundo astral em benefício da humanidade. Estes auxílios não são percebidos pelos encarnados que trabalham nos hospitais da terra e podem causar espanto, ou interpretação na forma de milagres.

[...] Fisicamente nosso amigo terá uma melhora, ou seja, uma resposta apreciável ao tratamento médico; porém, o perispírito dele ainda está envolvido em outro campo, criado pelas entidades do mal, que se utilizavam dele. Esse tipo de campo de força, que retém em seu interior o corpo espiritual do nosso irmão, só podemos desativar numa reunião mediúnica, o que ocorrerá amanhã. São necessárias as energias dos encarnados, associadas aos nossos recursos, a fim de destruir o campo que o envolve. Embora ainda se encontre em coma, o rapaz apresentará visível melhora do ponto de vista físico, como já dissemos. Entretanto, somente 
após a desestruturação do campo de retenção, na reunião mediúnica, ele acordará definitivamente. De qualquer forma, você pode reparar como a resposta atual, mesmo inexplicada, já é suficiente para animar a equipe do hospital. (PINHEIRO, 2004)

Uma enfermeira se aproximou do leito, olhou os instrumentos, mediu a pressão do rapaz e saiu rapidamente em busca de seus colegas. Vieram três médicos logo após, juntamente com mais dois enfermeiros. [...] A partir de agora, estarão ocupados desenvolvendo teorias e especulações científicas para explicar a melhora do nosso irmão. Amanhã, então, quando terminarmos o trabalho e ele acordar do coma profundo, seu caso passará para os registros como um daqueles "milagres", inexplicáveis pela medicina. (PINHEIRO, 2004)

As relações e os relacionamentos em sociedade envolvem aspectos de totalidade da prática cultural do grupo ao qual o indivíduo pertence. Esses aspectos englobam todo um conjunto de códigos e símbolos, de conhecimentos e saberes antigos e novos formando o repertório das representações sociais; construídas nesse terreno social e cultural, as representações estabelecem relações de sentido e fundamentam ações, sempre num movimento dialético. As representações religiosas são poderosos mecanismos construtores de sentido. A religião e a religiosidade podem oferecer, e quase sempre oferecem, um modo de compreensão da realidade que busca dar alivio aos sofrimentos. Nesta perspectiva, a explicação dos fatos da vida, no limite onde nossa ciência tradicional não consegue responder, podem ser encontrados em sistemas alternativos de resposta de caráter mágico ou religioso. A explicabilidade oferecida pelo espiritismo mostra toda a sua força quando as pessoas se veem confrontadas com o infortúnio. O entendimento e consequente melhor aceitação do infortúnio como decorrente da "lei de causa e efeito", introduz um nível mais alto de racionalização e de auto-responsabilização moral na explicação de doenças e desgraças pessoais, podendo apresentar uma alternativa, tanto em nível pessoal quanto social, para restabelecer um bem-estar na vida. O acréscimo da abordagem da Umbanda sobre essa ótica espírita pode ser uma proposta capaz de gerar novas maneiras de relacionamentos entre os adeptos dessas religiões.

\section{Considerações finais}

Os romances mediúnicos de Robson Pinheiro têm como proposta explícita relatar as atividades desenvolvidas pela
Umbanda no plano astral, mostrando o trabalho de pretosvelhos, exus e caboclos como necessário e benéfico; seu objetivo é de eliminar o preconceito dos adeptos do Espiritismo Kardecista em relação a ela. Os aspectos desenvolvidos nos romances analisados favorecem o entendimento da relevância das atividades da Umbanda, tanto no plano terreno quanto no plano "astralino" - do Além -, e buscam mostrar, dentro da explicabilidade do Espiritismo Kardecista, como estas ações são meritórias para a sociedade. Parafraseando Geertz, podemos dizer que se para o "estrangeiro" ou "visitante" uma manifestação religiosa pode ter valor estético ou de pesquisa, para o crente ela é materialização, interpretação, realização, não apenas como modelo daquilo que acreditam, mas como modelo para a crença. (GEERTZ, 1989). Os aspectos morais e estéticos (ethos) e os aspectos cognitivos (visão de mundo) dessa "Umbanda Branca" aparecem de modo claro nos romances escolhidos: o carma, a comunicabilidade entre os mundos e a saga moral da elevação do espírito são os elementos fundamentais. A partir deles tudo pode, no limite, ser explicado, inclusive aqueles fatos desafiadores que são geradores de sofrimento. Crença e ritual se confirmam e apresentam o "modelo daquilo que acreditam e o modelo da sua crença".

As descrições feitas nos romances espíritas, quando cotejadas com a literatura acadêmica, mostram que muito da realidade vista por estudiosos da Umbanda está aí incluída, especialmente no que tange à questão do surgimento da Umbanda no País. É preciso destacar, contudo, que os estudiosos da Umbanda nunca estiveram preocupados em distinguir a "Verdadeira" e a "Falsa" Umbanda, embora possamos traçar certos paralelos: alguns dos primeiros estudiosos da religião umbandista (como Bastide, por exemplo) viam-na como uma espécie de "produto espúrio", antes magia que religião, dada a sua ação voltada à consulta e solução de problemas; a herança religiosa Banto também foi vista como mais pobre culturalmente que a herança sudanesa no Brasil (Arthur Ramos, por exemplo) e, nesse sentido, o Candomblé nos moldes gêge-nago também era visto como um exemplo superior e verdadeiro de religião. Finalmente, não podemos esquecer que a discussão da pureza foi uma temática persistente nos estudos do Candomblé em décadas passadas; a Umbanda por sua vez, sempre foi vista como produto de múltiplos sincretismos e, desse modo, sua pureza não era assunto de controvérsias acadêmicas.

O mito de fundação da religião e os aspectos concernentes à Umbanda dita branca são descritos e explicados pela ótica espírita kardecista no sentido de somar ações em benefício dos indivíduos encarnados e desencarnados. A própria escolha 
de uma linha de construção da História da Umbanda no Brasil se mostra como um dos pontos mais significativos dos trabalhos analisados, pois encontramos aqui um verdadeiro processo de "invenção de tradições" da mais alta significação para estudiosos e adeptos das religiões envolvidas.

\section{Referências}

BAIRRÃO, J.F.M.H.; LEME, F.R. Mestres Bantos da Alta Mogiana: tradição e memória da Umbanda em Ribeirão Preto. Memorandum, n.4, p.5-32, 2003. Disponível em: http:// www.fafich.ufmg.br/ memorândum/artigos04/bairrao02. htm. Acesso em: 12 mar. 2010.

BERGER, P.L. O dossel sagrado: elementos para uma teoria sociológica da religião. São Paulo: Paulus, 1985.

GASPARETTO, Z. Laços eternos. São Paulo: Vida e Consciência Editora, 2003.

GASPARETTO, Z. Ninguém é de ninguém. 61. ed. São Paulo: Vida e Consciência Editora, 2008.

GEERTZ, C. A Interpretação das culturas. Rio de Janeiro: Editora LTC, 1989.

GIGLIO-JACQUEMOT, A. Médicos do astral e médicos da terra: as relações da umbanda com a biomedicina. Mediações: Revista de Ciências Sociais. v. 11, n.2, p.83-98, 2006.

GODOY, M.L.M. Em contato com o espaço do além: proposta para uma geografia do espiritismo. Revista de Estudos da Religião, p.1-20, 2009

LEWGOY, B. Chico Xavier e a cultura brasileira. Revista de Antropologia, v.44, n.1, 2001. [doi: 10.1590/S003477012001000100003].

PINHEIRO, R. Aruanda. 8. ed. Contagem: Casa dos Espíritos, 2004. 280p

PINHEIRO, R. Legião: um olhar sobre o reino das sombras. 5. ed. Contagem: Casa dos Espíritos, 2006. 502p.

PINHEIRO, R. Tambores de Angola. 2. ed. rev. e amp. 2006. Contagem: Casa dos Espíritos, 1998. 256p.

ROHDE, B.F. Umbanda, uma religião que não nasceu: breves considerações sobre uma tendência dominante na interpretação do universo umbandista. In: ENCONTRO DE ESTUDOS MULTIDISCIPLINARES EM CULTURA, 5., 2009, Salvador. Anais... Salvador: Faculdade de Comunicação/UFBA, 2009.

STOLL, S.J. O espiritismo na encruzilhada: mediunidade com fins lucrativos. Revista USP. São Paulo, n.67, p.176-185, 2005. Disponível em: http://www.usp.br/revistausp/67/12stoll.pdf. Acesso em: 3 abr. 2010.

VILLAS BOAS CONCONE, M.H. Percursos do labirinto: sincretismos da umbanda. In: TÓTORA, S.; BERNARDO, T. (Orgs.). Ciências Sociais na Atualidade. São Paulo: Cortez, 2003. p.259-275 